\title{
Assessing interdisciplinary learning and student activism in a Water issues course
}

\author{
Anja Mueller ${ }^{1 *}$, Stephen J. Juris ${ }^{2}$, Cathy Willermet ${ }^{3}$, Eron Drake ${ }^{4}$, Samik Upadhaya ${ }^{1}$ and \\ Pratik Chhetri $^{1}$
}

\begin{abstract}
In response to a request from a campus student organization, faculty from three fields came together to develop and teach an integrated interdisciplinary course on water issues and social activism. This course, "Water as Life, Death, and Power," brought together issues from the fields of anthropology, biology and chemistry to explore water rights, access to clean water, and water treatment methods. Students enrolled in the course developed interdisciplinary projects related to a variety of local and global water issues to present real-world solutions at a university-wide student research showcase. This article reports the assessment outcomes of the course, measuring changes in both interdisciplinary learning and levels of student activism.
\end{abstract}

Keywords: Course design, interdisciplinary assessment, water issues, student activism.

\section{Background}

Universities Allied for Essential Medicines (UAEM) is a coalition of undergraduate, graduate and professional students at academic institutions worldwide dedicated to providing global access to affordable medicines. The student group at Central Michigan University (CMU) indicated that they are interested in undergraduate courses that combined interdisciplinary teaching with solving real world problems, combining theory with activism. Three CMU UAEM faculty advisors took up the challenge to develop such a course: Stephen Juris (Biology); Anja Mueller (Chemistry); and Cathy Willermet (Anthropology). We decided to develop a course that would bridge all three disciplines around a complex problem and encourage both interdisciplinary thinking and activism in our students.

\section{Interdisciplinary Teaching and Learning}

The students requested an interdisciplinary course as a result of their involvement with UAEM, personal and professional interests, and because they understood that the complex problems their generation will have to solve would require people from different disciplines to work together and come up with a complex solution. In addition to the advantages of interdisciplinary learning identified by the students, researchers (e.g., Begg and Vaughan, 2011;

\footnotetext{
1 Department of Chemistry, Central Michigan University.

2 Department of Biology, Central Michigan University.

${ }^{3}$ Department of Sociology, Anthropology, and Social Work, Central Michigan University.

${ }^{4}$ Faculty Center for Innovative Teaching, Central Michigan University.

* Co-first authors
} 
Barisonzi \& Thorn, 2003; Eisen, Hall, Lee, \& Zupko, 2009; Nissani, 1997) discuss the advantages of interdisciplinarity, which include the fact that often interesting research topics fall in-between fields, that interdisciplinarity may help with communication difficulties between disciplines, and that creativity and flexibility is enhanced by interdisciplinary knowledge.

To teach interdisciplinary subject matter, it is generally accepted that disciplinary grounding is required. That does not mean, though, that students have to be experts in the breadth of several disciplines, but rather that students understand concepts from several disciplines in depth so that they can use them together to develop something new (Mansilla \& Duraisingh, 2007; DeZure, 2010). Faculty also do not have to be experts in a breadth of several disciplines, but in this context, need to be open to examining and encouraging exploration of diverse ways of thinking in multiple disciplines.

The students also asked to include activism into an interdisciplinary course on real-world problems, which, in our context for the course, translated into problem-solving processes. There is a large body of literature that supports problem-based learning as an effective teaching tool (e.g. Nilson, 2010; Prince, 2004). In fact, some colleges and universities are now offering interdisciplinary, problem-based undergraduate degrees (Sternberg, 2008). Thus, we decided to incorporate problem-based, interdisciplinary group work into our course as a tool to teach the students the basics of effective activism.

\section{Interdisciplinary Course Development}

We first had to decide how we would integrate the three disciplines. Universities usually teach separately in disciplines, resulting in students that are not exposed to interdisciplinary thinking. Therefore, we decided to model interdisciplinary thinking in the way we taught the lectures. The three faculty (Juris, Mueller, and Willermet) taught each lecture together and modeled interdisciplinary thinking by discussing each topic from all three points of views, then synthesizing the lecture, often in an interactive discussion with the students. (For specific details about course development, please see Willermet et al., 2013).

Utilizing a "point-of-the-day" strategy, we developed the lecture content and facilitated the lectures. This "point-of-the-day" strategy served to focus content on only the necessary facts and helped to scaffold content information into a continuous, interrelated story that aligned with the student learning objectives instead of a collection of facts. Also, by developing the content together as well as teaching it together, we were able to look at each concept that we had agreed on as important from all disciplinary viewpoints and discuss the integration in class, modeling it for the students as they were learning the concepts. Thus, we taught them how to integrate knowledge in an interdisciplinary manner (Haynes, n.d.). In brief, as one example, when we talked about how humans impact water quality and availability, we discussed the nitrogen cycle and fertilizer as a water pollutant (Chemistry), algae blooms (Biology), and aquifer depletion as an effect of human water use that affects water access (Anthropology). We asked the students what additional effects humans could have on water access and quality, eventually adding to the discussion additional examples we had prepared in advance.

Equally important, we added a seminar portion to the class, which included group work and interdisciplinary problem solving, allowing the students to practice working in a group and implementing and integrating interdisciplinary understanding to develop an activism strategy. 


\section{Interdisciplinary Course Goals and Objectives}

Student learning outcomes (SLO) are sometimes challenging to assess effectively in an interdisciplinary freshmen course; for students to gain truly interdisciplinary understanding to a point that they can apply it to solve an interdisciplinary problem in a group setting, they have to first gain several skills, such as working in a group, and then synthesize and combine information from different disciplines. Since this class is designed for freshmen/sophomores, it has to be assumed that these skills need to be taught during the class as well. Thus, assignments and grading rubrics needed to consider how students will demonstrate their attainment of the SLOs related to interdisciplinary understanding in not only the final product, but the various steps that lead to this outcome.

In addition to the SLO focused on water issues, we identified two additional overarching goals for the course: 1) developing interdisciplinary thinking rather than focusing specifically on content; and 2) encouraging students to engage in actively solving current, real-world problems in an interdisciplinary way. (See the Master Course Syllabus, Appendix 1). We considered collaborative learning to be an essential goal to allow students to see how real-world complex problems can be solved in real-life.

We hypothesized that: 1) students would increase their knowledge about water and waterrelated issues, such as water chemistry, water-borne pathogens, and global access to clean water; 2) students would increase their desired level of social activism; and 3) students would increase their interdisciplinary thinking. These hypotheses guided our assessment efforts, as described below.

\section{Research Design and Methods}

Our research design included two separate assessment strategies: a pre-post survey to address hypotheses one and two, and an interdisciplinary project to address hypothesis three.

We obtained Internal Review Board (IRB) approval (CMU 377609-2) to collect student data assessing whether students increased their competency in interdisciplinary thinking, as well as increased their knowledge of activism and human rights. The Internal Review Board approval extended to administration of a pre- and post-course survey and application of a rubric to specific group-assigned course activities to assess interdisciplinary thinking. On the first day of class, we invited interested students to join us in a research study that would help assess how well they learned about water issues, their level of activism, and degree of interdisciplinary thinking. Students received a manila envelope that contained two copies of the consent form, a bubblesheet response form, and two surveys, the research survey and a similar-looking alternate survey. If students wished to participate, they signed a consent form and completed the research survey; if not, they completed the alternate. Both surveys and bubble sheet were returned to the envelope. One author, Eron Drake, acted as the project's "honest broker." She assigned each student a randomly generated three-digit code and kept the key of student names and keys in a secure, locked location. The instructional team does not know which students participated in the study; students received the same number of points for completing either survey.

There were 29 students that registered and completed the course. Of the 29 students registered for the course that ultimately completed the course, 12 were male and 17 were female. These students registered for the course in one of three disciplines (anthropology, biology, and chemistry); 15 students registered under the anthropology designator, 13 students registered

Journal of the Scholarship of Teaching and Learning, Vol. 14, No. 2, May 2014. 
under the biology designator, and 1 registered under the chemistry designator. Twenty-eight students completed the pre- and post-test associated with the research project.

Interdisciplinary thinking can be difficult to assess through objective means such as multiple-choice exams. Rather, interdisciplinary thinking can be better assessed through projects, essays, and discussion. To that end, we assigned a semester-long group project for which students chose a water-related problem and developed an interdisciplinary solution and a strategy for implementation. The proposed solution had to include perspectives from anthropology, biology, and chemistry. We decided to break up the interdisciplinary project development process into several steps; we needed to start groups out with a solid, disciplinary foundation for their project, before we could start them on the steps to integrate that information by bridging the concepts, integrating them into a complex discussion and finally into an interdisciplinary solution to the problem (Mansilla \& Duraisingh, 2007). In this manner, the students could practice and improve their interdisciplinary understanding and implementation strategy.

We started with a group contract, to make sure that all students understood their role in the group and could solve problems within the groups more easily. One of the authors (Eron Drake) prepared the students for group work and group contract by presenting them with information about group formation, group roles, and group expectations, and giving them examples for group contracts. Students next completed a problem statement so that the groups had to decide early what exactly to work on. This problem statement needed to include how the three disciplines would be part of the solution. Students were also taught how to search for materials for their project in the library. The material was mostly disciplinary and part of the disciplinary grounding for the project.

Groups were then asked to complete a concept map to develop the connections between the different fields in relationship to their specific problem solution. Building this concept map allowed the students to bridge the different concepts into a first step towards interdisciplinary understanding. The next step was a short, persuasive pitch and an abstract to make sure the groups stayed focused and provide them a means to practice how to present their work. The final project was a poster presentation of their final complex solution strategy for a complex water problem at a campus-wide event. The final project included an interdisciplinary discussion of the problem, as well as the integrative solution the students came up with. At the same time students had to present and pitch their solution to the "general public" as any activist would have to do. We met with the groups at each stage to give them maximum feedback and opportunity for questions.

We were concerned that a heightened interest in assessing interdisciplinarity would bias us to see it more often than students were in fact presenting it. To reduce this bias, we employed a grading rubric for any assignments that required subjective assessment (see below and Appendix 2). The assessment of the group projects for interdisciplinary understanding was developed according to the steps in student learning (Mansilla \& Duraisingh, 2007). The first step in this process is to have an effectively presented disciplinary argument (Disciplinary Grounding). To assess disciplinary grounding, we modified our assessment using the Universal Intellectual Standard developed by Drs. Paul and Elder from the Center for Critical Thinking (Elder \& Paul, 2013). When we graded the interdisciplinary assignments, each faculty evaluated students for this section based on their discipline. We based the interdisciplinary part of the rubric on Mansilla and Duraisingh's snapshots of interdisciplinary integration (Mansilla \& Duraisingh, 2007). We used integrative summary, conceptual bridging, and complex explanation as the three consecutive steps of interdisciplinary understanding in our rubric. 
The group project in this class asked specifically for a solution of a water-related problem. Therefore we needed an additional part for our rubric assessing the pragmatic solution the students proposed. We based the evaluation on Six Sigma, which was invented by a Motorola researcher and is used in industrial project evaluations (Motorola University, 1994). Our guest lecturer, Keith Helferich, presented the basis of Six Sigma to our students as several steps that have to be completed for a successful project: Define (plan), measure (do), analyze (review performance, identify opportunities, root causes, and effects), improve (prioritize actions to enhance performance), and control (implement and establish future assessment program). We wrote the solution assessment on these five steps. The full rubric can be found in Appendix 2 .

As mentioned above, students would have to learn all of the steps outlined in the Interdisciplinary Assessment Rubric (Appendix 2) during the class, which takes careful planning and the allotment of time-on-task to enhance student learning. Instruction must be scaffolded to allow for students to develop and practice higher-level cognitive skills associated with interdisciplinary learning. Therefore, we decided to use the rubric in the evaluation of many of the project assignments, but we weighed the three parts (disciplinary grounding, interdisciplinary reasoning, and pragmatic solution) differently throughout the semester. We first weighed disciplinary grounding more heavily than interdisciplinary reasoning, next weighed them equally, and at the end weighed disciplinary grounding least and the pragmatic solution most. Using this redistribution of weighting, we accounted for the increasing interdisciplinary understanding throughout this course.

Two specific assignments provided an excellent opportunity to evaluate student gains in interdisciplinary thinking. The first was the concept map that each group drew at the beginning of their project, to describe how the disciplines would interact in their proposed research. The second was the final presentation that described their problem and proposed solution. We assessed the interdisciplinary understanding at these two stages of their group projects using our interdisciplinary rubric. All instructors of the course separately utilized this rubric to grade every assignment. We then averaged the grades over all instructors to finalize the assignment grade. When disciplinary grounding needed to be established, each of the instructors with expertise in the questioned disciplinary grounding provided guidance on grading criteria.

\section{Goal 1: Increased Knowledge of Water-Related Issues}

The student pre-post survey contained questions designed to measure overall student factual knowledge of water-related issues. Students were asked nine questions to assess their overall knowledge of water-related material. The source of the questions was the course textbook. We used the textbook mostly as a reference, with content provided from the lecture materials and supplemental readings. Therefore these questions were not a direct measure of specific fact retention.

To analyze whether factual answers improved over the semester, data were analyzed statistically in $\mathrm{R}$ (version 3.0.1) (R, 2013) using a generalized linear model with a binomial error distribution. Calculated probability values were deemed significant with $\mathrm{a}=0.05$ using a sequential Bonferroni adjustment for each question. 


\section{Goal 2: Increased Student Interest in Social Activism}

The student pre-post survey also contained questions designed to measure a change in student familiarity with water-related issues and their interest in activism. This evaluation included questions about the student's awareness of water issues, to assess the student's personality, the student's interest in volunteering within the university, and about the civic engagement and social awareness of the student.

These questions were posed on a five-point Likert scale. On questions with a Likert scale, increasing values might mean a decrease or increase of improvement, depending how the question was asked. For the statistical analysis, all Likert scales were adjusted so that increasing values meant improvement. Student responses were categorized into three different groups, students who agreed with a statement (i.e. answered 4 or 5 on the Likert scale), students who disagreed with a statement (i.e. answered 1 or 2 on the Likert scale), or students who were neutral about a statement (i.e. answered 3 on the Likert scale). Student responses were paired pre-post, and changes in student opinion in a positive (disagree/neutral stance pre-test to agree stance post-test) or negative (agree stance pre-test to disagree/neutral stance post-test) were analyzed using a McNemar's test and calculating chi-squared. A p-value was obtained using one degree of freedom, and a value of $p<0.05$ was interpreted as a significant change comparing pre- and post-test data.

\section{Goal 3: Increased Interdisciplinary Thinking}

To measure if the interdisciplinary reasoning of the students increased from an earlier assignment (concept map) to the final assignment (poster presentation), we compared student performance on the interdisciplinary sections of the rubric as applied to these two assignments (See Appendix 2). For each of the assignments, assigned points and weights differed due to the nature of the individual assignment. For example, points were given for staying within a 3minute time limit for the persuasive pitch; the final presentation included a self- and peerassessment. We needed to remove the effects of these points on the assignment grade, to isolate points related to interdisciplinary understanding and problem solving. To exclude the effect of all other rubric sections and other points that were included in the grade, it was assumed that the students obtained full points for everything but the interdisciplinary section of the rubric. These points were averaged across all groups. We then compared the remaining points assigned exclusively for interdisciplinary reasoning. This technique should, if anything, underestimate the students' performance on interdisciplinary learning. Since the data were organized in this way, we did not perform a statistical analysis, but rather calculated the mean group performance on this measure between the two assignments.

\section{Results and Discussion}

The following discusses the results obtained in exploration of our hypotheses:

1) students would increase their knowledge about water and water-related issues, such as water chemistry, water-borne pathogens, and global access to clean water; 2) students would increase their desired level of social activism; and 3) students would increase their interdisciplinary thinking. 
Mueller, A., Juris, S. J., Willermet, C., Drake, E., Upadhaya, S., \& Chhetri, P.

\section{Goal 1: Increased Knowledge of Water-Related Issues}

The data reported (Table 1) indicate that students gained a deeper overall knowledge of water-related material, although the overall increase is not significant and performance on three of the questions decreased. There was a statistically significant improvement on both the question connected to water required to make one calorie of food $(21 \%$ increase in correct responses during post-test compared to the pre-test) and the question connected to which food type takes the most water to produce one kilogram of food $(18 \%$ increase in correct responses during post-test compared to the pre-test). There was decline on questions related to water access, which saw a 7\% decline in correct answers; however this decrease was not statistically significant.

Table 1

Student familiarity with material questions related to water $(\mathrm{N}=28)$

\begin{tabular}{|c|c|c|c|c|}
\hline & $\begin{array}{l}\text { Pre-Test } \\
\text { Correct } \\
\text { Answer }\end{array}$ & $\begin{array}{l}\text { Post-Test } \\
\text { Correct } \\
\text { Answer }\end{array}$ & $\begin{array}{c}\% \\
\text { Change }\end{array}$ & $\mathrm{p}$ value \\
\hline \multicolumn{5}{|l|}{$\begin{array}{l}\text { "Please answer the questions below with your } \\
\text { best answer." }\end{array}$} \\
\hline $\begin{array}{l}\text { How many people in the world do NOT have } \\
\text { consistent access to drinking water? }\end{array}$ & 17 & 15 & $-7 \%$ & 0.31 \\
\hline $\begin{array}{l}\text { How much water does it take to make one calorie } \\
\text { of food? }\end{array}$ & 7 & 13 & $21 \%$ & $0.012^{*}$ \\
\hline $\begin{array}{l}\text { How many calories of food per day are needed } \\
\text { for an average } 175-1 \text { male to maintain his body's } \\
\text { basic metabolic functions at rest? }\end{array}$ & 4 & 6 & $7 \%$ & 0.15 \\
\hline $\begin{array}{l}\text { How much water does it take to produce one } \\
\text { calorie of energy? }\end{array}$ & 7 & 6 & $-4 \%$ & 0.59 \\
\hline $\begin{array}{l}\text { What percentage of water withdrawals is used for } \\
\text { agriculture? }\end{array}$ & 4 & 8 & $14 \%$ & 0.041 \\
\hline The biggest threat to our global water supply is: & 10 & 11 & $4 \%$ & 0.64 \\
\hline $\begin{array}{l}\text { The ratio of people who don't have water piped } \\
\text { into their homes is: }\end{array}$ & 18 & 16 & $-7 \%$ & 0.37 \\
\hline $\begin{array}{l}\text { In an average industrialized country, the average } \\
\text { household uses what percentage of its water use } \\
\text { to flush the toilet? }\end{array}$ & 6 & 9 & $11 \%$ & 0.10 \\
\hline $\begin{array}{l}\text { Which food type takes the most water to produce } \\
\text { one kilogram of food? }\end{array}$ & 13 & 18 & $18 \%$ & $0.015^{*}$ \\
\hline
\end{tabular}

Note: * denotes significance at the $\mathrm{p}=0.05$ level.

\section{Goal 2: Increased Student Interest in Social Activism}

The student pre-post survey contained questions designed to measure overall student interest in water-related issues and degree of student activism. Students were asked 48 questions to assess their agreement with statements connected to clean water access and degree of willingness to play a role in university and/or community activism. Questions were rated on a 
five-point Likert scale, for which one indicates "strong disagreement" and five indicates "strong agreement". Students were pooled into one of two categories depending on their answers to the questions - 1) students who answered 1-3 for a question (i.e. disagreed/neutral with the question), and 2) students who answered 4 or 5 for a question (i.e. agreed with the question). The data reported (Table 2) represent percent changes in each of these two categories when comparing pre-test and post-test answers, where a negative change was scored when a student answered 4 or 5 on the pre-test and 1-3 on the post-test, and a positive change was scored when a student answered 1-3 on the pre-test and 4 or 5 on the post-test. Results indicate that students gained a deeper appreciation and understanding of water-related issues. Of note was a statistically significant greater agreement with statements concerning the potential for a water crisis in America (39.3\% increase in students agreeing post-test) and a statistically significant stronger agreement on the negative impact of bottled water on the world's water supply (35.7\% increase in students agreeing post-test). Furthermore, there was a statistically significant stronger agreement in students when asked whether social problems directly affect the quality of life in their community (32.1\% increase in students agreeing post-test)

Interestingly, data collected indicate that students changed their potential for civic engagement, and this change seemed to be a refocusing of student energy away from university organizations towards community involvement. There was a trend in students disagreeing with questions asking about plans to become involved in university organizations (although not statistically significant) with a concurrent increase in the importance of civic engagement issues. However, this may be an inadvertent artifact of the question text, which asks, "During this term, to what degree do you intend to..." As a pre- term question, it asks the student what he/she might do in the near future. However, as a post-term question, students might answer in the negative either as the term is over and they don't intend to do it in the next few days, or since they know they didn't in fact do it this term. The wording of this question might not capture student intent in the future.

Every question concerning civic engagement issues showed an increase in agreement with the statements posed, with ten showing statistically significant increases: participating in a community action program $(17.9 \%$ positive increase post-test, $\mathrm{p}=0.0253)$; helping promote racial understanding $(25 \%$ positive increase post-test, $\mathrm{p}=0.0082)$; influencing social values ( $25 \%$ positive increase post-test, $\mathrm{p}=0.0082)$; finding a career that directly benefits others $(25 \%$ positive increase post-test, $\mathrm{p}=0.0082)$; giving some income to those in need $(28.6 \%$ positive increase post-test, $\mathrm{p}=0.0196)$; becoming a community leader $(25 \%$ positive increase post-test, $\mathrm{p}$ $=0.0339)$; working toward equal opportunity for all people $(17.9 \%$ positive increase post-test, $\mathrm{p}$ $=0.0253)$; viewing social issues from multiple perspectives $(25 \%$ positive increase post-test, $\mathrm{p}=$ $0.0082)$; developing a meaningful philosophy of life $(25 \%$ positive increase post-test, $\mathrm{p}=$ $0.0339)$; and developing leadership abilities in others $(25 \%$ positive increase post-test, $\mathrm{p}=$ 0.0339). There were correlative increases in other questions including participating in programs to help clean up the environment (25\% positive increase post-test), serving the community (17.9\% positive increase post-test) and participation in voting (28.6\% positive increase post-test), although these increases were not statistically significant. It is interesting to speculate that a shift from focus on involvement in student organizations to involvement in community organizations may be due to a redefined student view on the ability to affect change within the community more directly depending on the organization with which they are involved. 
Mueller, A., Juris, S. J., Willermet, C., Drake, E., Upadhaya, S., \& Chhetri, P.

Table 2

Student Familiarity with Clean Water Issues and Willingness to Participate in Social Activism $(\mathrm{N}=28)$

\begin{tabular}{|c|c|c|c|}
\hline \multicolumn{4}{|c|}{ "Please rate the level to which you agree (or disagree) with each of t } \\
\hline & $\begin{array}{l}\% \text { students } \\
\text { with negative } \\
\text { change }\end{array}$ & $\begin{array}{c}\% \text { students } \\
\text { with positive } \\
\text { change }\end{array}$ & p-value \\
\hline $\begin{array}{l}\text { Access to clean water is a problem all } \\
\text { Americans face }\end{array}$ & 10.7 & 17.9 & 0.4795 \\
\hline $\begin{array}{l}\text { Access to clean water is something that } \\
\text { only people in developing nations face }\end{array}$ & 3.6 & 7.1 & 0.5637 \\
\hline $\begin{array}{l}\text { We will face a water shortage in } \\
\text { America in the next few decades }\end{array}$ & 0 & 39.3 & $0.0009 *$ \\
\hline $\begin{array}{l}\text { Irrigation systems are generally water } \\
\text { wasters }\end{array}$ & 10.7 & 21.4 & 0.3173 \\
\hline $\begin{array}{l}\text { Drinking commercially bottled water } \\
\text { contributes to global water shortages }\end{array}$ & 7.1 & 35.7 & $0.0209 *$ \\
\hline $\begin{array}{l}\text { We are losing lots of available water } \\
\text { due to climate change }\end{array}$ & 17.9 & 17.9 & 1 \\
\hline \multirow{2}{*}{$\begin{array}{l}\text { Cholera is a disease that people get } \\
\text { when they don't keep themselves clean }\end{array}$} & 7.1 & 7.1 & 1 \\
\hline & $\begin{array}{c}\% \text { students } \\
\text { with negative } \\
\text { change }\end{array}$ & $\begin{array}{c}\% \text { students } \\
\text { with positive } \\
\text { change }\end{array}$ & p-value \\
\hline Participate in a student organization & 10.7 & 3.6 & 0.3173 \\
\hline $\begin{array}{l}\text { Hold a leadership position in a } \\
\text { college/university student organization }\end{array}$ & 7.1 & 7.1 & 1 \\
\hline Participate in class discussions & 21.4 & 7.1 & 0.1573 \\
\hline $\begin{array}{l}\text { Investigate current events topics of } \\
\text { personal interest }\end{array}$ & 17.9 & 10.7 & 0.4795 \\
\hline \multirow{2}{*}{$\begin{array}{l}\text { Volunteer my time to an organization or } \\
\text { cause I care about }\end{array}$} & 25 & 17.9 & 0.5637 \\
\hline & $\begin{array}{l}\% \text { students } \\
\text { with negative } \\
\text { change }\end{array}$ & $\begin{array}{c}\% \text { students } \\
\text { with positive } \\
\text { change }\end{array}$ & p-value \\
\hline $\begin{array}{l}\text { I believe that every citizen has a } \\
\text { responsibility to serve the community }\end{array}$ & 21.4 & 10.7 & 0.3173 \\
\hline $\begin{array}{l}\text { I am concerned about local community } \\
\text { issues }\end{array}$ & 14.3 & 17.9 & 0.7389 \\
\hline $\begin{array}{l}\text { I am concerned with the rights and } \\
\text { welfare of others }\end{array}$ & 7.1 & 17.9 & 0.2568 \\
\hline $\begin{array}{l}\text { I am interested in knowing and working } \\
\text { with people from diverse backgrounds }\end{array}$ & 14.3 & 7.1 & 0.4142 \\
\hline $\begin{array}{l}\text { I believe that cultural diversity within a } \\
\text { group makes the group more interesting } \\
\text { and/or effective }\end{array}$ & 0 & 10.7 & 0.0833 \\
\hline
\end{tabular}


Mueller, A., Juris, S. J., Willermet, C., Drake, E., Upadhaya, S., \& Chhetri, P.

I feel that social problems directly affect the quality of life in my own community I see myself as a member of a larger social fabric

I have a responsibility to serve my community

I feel that I can make a difference in my

local community

I feel that I can make a difference in the world

I view myself as an active citizen

I am concerned about global community issues
0

10.7

21.4

7.1

14.3

7.1

14.3
32.1

14.3

10.7

14.3

21.4

21.4

21.4
$0.0027^{*}$

0.7055

0.3173

0.4142

0.5271

0.1573

0.5271

\begin{tabular}{|c|c|c|c|}
\hline & $\begin{array}{c}\% \text { students } \\
\text { with negative } \\
\text { change }\end{array}$ & $\begin{array}{c}\% \text { students } \\
\text { with positive } \\
\text { change }\end{array}$ & p-value \\
\hline $\begin{array}{l}\text { Participating in a community action } \\
\text { program }\end{array}$ & 0 & 17.9 & $0.0253 *$ \\
\hline Helping others who are in difficulty & 7.1 & 21.4 & 0.1573 \\
\hline Helping promote racial understanding & 0 & 25 & $0.0082 *$ \\
\hline $\begin{array}{l}\text { Becoming involved in programs to help } \\
\text { clean up the environment }\end{array}$ & 7.1 & 25 & 0.0956 \\
\hline Influencing social values & 0 & 25 & $0.0082 *$ \\
\hline Influencing the political structure & 10.7 & 21.4 & 0.3173 \\
\hline Serving the community & 3.6 & 17.9 & 0.1025 \\
\hline $\begin{array}{l}\text { Finding a career that directly benefits } \\
\text { others }\end{array}$ & 0 & 25 & $0.0082 *$ \\
\hline $\begin{array}{l}\text { Giving some of my income to help } \\
\text { those in need }\end{array}$ & 3.6 & 28.6 & $0.0196^{*}$ \\
\hline Becoming a community leader & 3.6 & 25 & $0.0339 *$ \\
\hline Keeping up to date with political affairs & 10.7 & 17.9 & 0.4795 \\
\hline $\begin{array}{l}\text { Working toward equal opportunity for } \\
\text { all people }\end{array}$ & 0 & 17.9 & $0.0253 *$ \\
\hline $\begin{array}{l}\text { Viewing social issues from multiple } \\
\text { perspectives }\end{array}$ & 0 & 25 & $0.0082 *$ \\
\hline Promoting social justice & 7.1 & 21.4 & 0.1573 \\
\hline $\begin{array}{l}\text { Developing a meaningful philosophy of } \\
\text { life }\end{array}$ & 3.6 & 25 & $0.0339 *$ \\
\hline Developing leadership abilities in others & 3.6 & 25 & $0.0339 *$ \\
\hline $\begin{array}{l}\text { Participating in civic duties such as } \\
\text { voting }\end{array}$ & 10.7 & 28.6 & 0.1317 \\
\hline
\end{tabular}

Note: $*$ denotes significance at the $\mathrm{p}=0.05$ level.

The increased dedication of students becoming involved in a community issue was apparent based on the dedication students had of their group projects that they developed throughout the semester (connected to Goal 3 below). Several groups continued to seek outcomes of their projects after the semester had ended and had developed plans to further promote their project agenda through the formal submission of proposals or letters to their corresponding agencies/affected communities in order to affect change. 


\section{Goal 3: Increased Interdisciplinary Thinking}

The students had free choice of which problem they wanted to solve as collaborative groups. The groups came up with a list of problems and solutions spanning issues at local, regional, and international levels:

- Development of a time-release version of an existing anti-worming drug for schistosomiasis in Uganda, along with educational call-and-response children's song on how to avoid getting sick;

- A plastic water bottle deposit campaign to promote recycling and tap water usage;

- Installation of composting toilets at CMU to reduce water consumption;

- Community education on hydrologic fracturing to understand water contamination;

- Modification of city green-lawn ordinances to reduce local water contamination through chemical runoff;

- Analysis of strategies to connect Iowa farmers to government programs to promote bioswale buffer zones along the Mississippi River, to reduce downriver dead zones;

- Proposal to Mayoral Office in Copacabana, Bolivia to design totora reed beds that clean wastewater before it enters Lake Titicaca;

- Investigation of water disinfection techniques using solar UV radiation (SODIS) in plastic bottles in Uganda.

For the concept map, $32 \%$ of total points were available for interdisciplinary learning based on the rubric in Appendix 2. Students were graded on the concept maps based on development of their solution to a global problem and whether their solution contained the three disciplines associated with the course (anthropology, biology, chemistry) and was sustainable. For the final project, $45 \%$ of the points were assigned to interdisciplinary learning. The student groups' performance improved from an average of $40.1 \%$ of the total available points for interdisciplinary learning on the concept map to $71.6 \%$ of the total available points for the final project. The standard deviation decreased between the two assignments, from $22 \%$ to $11.8 \%$, which suggests that student groups as a whole performed more consistently on their final projects. All groups but one experienced a large improvement in performance on the interdisciplinary rubric; the remaining group (Group 5) was the highest performing group, doing very well on both assignments.

\section{Discussion}

Besides teaching anthropological, biological, and chemical facts about water, there were two overarching goals for the course that we assessed: 1) developing interdisciplinary thinking rather than focusing specifically on content; and 2) encouraging students to engage in actively solving current, real-world problems in an interdisciplinary way. Real world-problem solving often occurs in groups, combining different strengths and backgrounds. We wanted to mimic that; at the same time, benefiting the learning of diverse students in collaborative assignments and projects is also recognized as a high impact practice (Kuh, 2008). We encouraged the students to reach out to NGOs and other community groups in the process; this community connection, as well as the service rendered with the project, is considered a high-impact teaching process as well. 
Mueller, A., Juris, S. J., Willermet, C., Drake, E., Upadhaya, S., \& Chhetri, P.

As discussed above, the fact-based questions might not have been an accurate measure for students' content knowledge. Upon reflections, questions aligned with the content covered would better reflect content learning. The end-of-term Student Opinion Survey comments for each faculty did indicate that factual learning took place. Examples for the question "What are some specific things your instructor does that help you learn in this course?" are "Helped fill in knowledge for "non-chemists;" "Powerpoints - helped me learn Chemistry I had never understood before;" "There were always good examples and explanations on subjects covered for the Anthro portion of the class;" "Helped me understand biology that I had never learned before;" "For the non-bio student he explained things well so they were easy to understand."

Table 3

Comparison of Student Group Means for Interdisciplinary Learning Portion of Group Projects, as Percentage of Total Interdisciplinary Learning Points Possible (N=8)

\begin{tabular}{lccc}
\hline & Concept Map* & Final Project** & $\%$ Change \\
\hline Group 1 & $20.8 \%$ & $69.8 \%$ & $48.9 \%$ \\
Group 2 & $50.0 \%$ & $73.4 \%$ & $23.4 \%$ \\
Group 3 & $4.2 \%$ & $45.0 \%$ & $40.8 \%$ \\
Group 4 & $37.5 \%$ & $81.8 \%$ & $44.3 \%$ \\
Group 5 & $79.2 \%$ & $70.2 \%$ & $-8.9 \%$ \\
Group 6 & $37.5 \%$ & $72.0 \%$ & $34.5 \%$ \\
Group 7 & $50.0 \%$ & $79.8 \%$ & $29.8 \%$ \\
Group 8 & $41.7 \%$ & $80.9 \%$ & $39.2 \%$ \\
\hline Mean percentage & $40.1 \%$ & $71.6 \%$ & $31.5 \%$ \\
Standard deviation & $22.0 \%$ & $11.8 \%$ & \\
\hline
\end{tabular}

*Note: $32 \%$ of the total points for the concept map assignment aligned with interdisciplinary learning goals.

** Note: $45 \%$ of the total points for the final project assignment aligned with interdisciplinary learning goals.

On the students' social activism, the awareness about critical water problems increased significantly. Interestingly, the willingness to participate socially in the university decreased (although this may be an artifact of the question wording, as discussed above). On the other hand, becoming active in the community at large increased significantly; in fact, it was the largest change measured. 
Interdisciplinary understanding was measured by a rubric for the group projects that assessed the three steps of interdisciplinary learning, disciplinary grounding, interdisciplinary bridging, and interdisciplinary problem solving. The students became proficient in the disciplinary information early, but it took most of the semester for them to become proficient in interdisciplinary bridging and problem solving. At the end we were able to show a significant increase in interdisciplinary learning.

\section{Acknowledgements}

We wish to thank each of the department chairs, who supported our efforts in developing this course: Stephen Roberts (Biology), David Ash (Chemistry), and Katherine Rosier (Sociology, Anthropology, and Social Work), as well as Dean Pamela Gates (College of Humanities and Social and Behavioral Sciences) and Dean Ian Davison (College of Science and Technology). We wish to acknowledge the hard work and countless hours that the UAEM students have gifted to this course development. CMU's Faculty Center for Innovative Teaching (FaCIT) supported this project with staff, funds, instructional support, and moral support. We extend our special thanks to all the students enrolled in the course, without whom this experiment would not have been possible. We also wish to thank Kevin Pangle (Biology, CMU), Elbert Almazan (SASW, CMU), and two anonymous reviewers for help with statistical analyses.

\section{Appendices}

Appendix 1: Master Course Syllabus

Central Michigan University

College of Science and Technology

Department of Biology

Master Course Syllabus

$\underline{B I O} 250$

Water as Life, Death, and Power

$\underline{3(2-2)}$

Credit

\section{Bulletin Description}

Problems of water access, water-borne pathogens, water treatment, and power relationships in global cultures from anthropology, biology, and chemistry perspectives, via lecture and seminar. Cross-listed with ANT 250 and CHM 250. No credit on chemistry major or minor. No credit towards any Biology major or minor.

\section{Prerequisites, Pre/Co-requisites, Co-requisites, Recommended}

Recommended: ANT 171 or 170; BIO 101 or 110; CHM 111, 120, or 131.

\section{Rationale for Course Level}

This course will be taught in an interdisciplinary manner, and will include material from anthropology, chemistry, and biology. It will foster synthesis of information from all three disciplines in order to 
Mueller, A., Juris, S. J., Willermet, C., Drake, E., Upadhaya, S., \& Chhetri, P.

evaluate issues and interventions related to water access rights, health issues, and water treatment, thus is designed for a more mature undergraduate student with little content background.

\section{Suggested Textbooks}

The interdisciplinary nature of this course requires texts from several perspectives. Texts that will make up the readings include:

Black M, King J. 2009. The Atlas of Water. $2^{\text {nd }}$ edition. Berkeley: University of California Press.

Fagan B. 2011. Elixir: A History of Water and Humankind. London: Bloomsbury Press.

Morris RD. 2007. The Blue Death: Disease, Disaster, and the Water We Drink. New York: HarperCollins

Press.

American Chemical Society 2012. Chemistry in Context, 7th Edition. New York: McGraw Hill.

\section{Other Requirements and/or Materials for the Course}

Additional articles will be uploaded into Blackboard.

\section{Student Learning Course Objectives}

Upon completion of the course, students will be able to:

1. examine water-related health disparities from multiple perspectives, such as water access, water-borne pathogens, water treatment, and power relationships;

2. describe the interrelationships of these different perspectives;

3. describe the life-cycle of cholera and its connection to human health;

4. describe behaviors that bring populations in contact with cholera, and provide regional examples from many global cultures;

5. compare and contrast political, economic, and technological access to water treatment methods from different global cultures;

6. summarize and analyze seminar readings related to water-related health disparities, and intervention case studies, from different global cultures;

7. define a plan to develop or improve a grassroots campaign to address water issues.

\section{Suggested Course Outline}

\begin{tabular}{|l|l|l|}
\hline Week & Lecture topic & Seminar topic \\
\hline $6.67 \%$ & $\begin{array}{l}\text { Settlement patterns and water } \\
\text { Food collection/production strategies and water } \\
\text { A: Human food collection/production strategies and } \\
\text { their relative water needs } \\
\text { B: Biotic/abiotic factors affecting water cycle } \\
\text { C: Water cycle, Carbon cycle }\end{array}$ & Introduction to group work \\
& $\begin{array}{l}\text { Water chemistry } \\
\text { A: How human activity can alter water chemistry } \\
\text { B: Transport of molecules across membranes } \\
\text { C: water properties, acid-base, pH, solubility, } \\
\text { adsorption and ion exchange }\end{array}$ & $\begin{array}{c}\text { Introduction to non-governmental } \\
\text { organizations (NGOs) }\end{array}$ \\
& $\begin{array}{l}\text { Human co-evolution with pathogens } \\
\text { Waterborne diseases } \\
\text { A: Pathogens common to settled v. foraging human } \\
\text { groups } \\
\text { B: Host-pathogen interaction/evolution } \\
\text { C: dilution, adsorption }\end{array}$ & $\begin{array}{c}\text { Evidence-gathering approaches to } \\
\text { regional-specific diseases }\end{array}$ \\
& $\begin{array}{l}\text { Cultural practices and interaction with water (food } \\
\text { washing, bathing, food production, religious }\end{array}$ & \begin{tabular}{c} 
Cultural awareness and sensitivity \\
\hline $6.67 \%$
\end{tabular} \\
\hline
\end{tabular}

Journal of the Scholarship of Teaching and Learning, Vol. 14, No. 2, May 2014. 


\begin{tabular}{|c|c|c|}
\hline & $\begin{array}{l}\text { practices) } \\
\text { Sanitation } \\
\text { A: Cultural practices and water (food washing, } \\
\quad \text { bathing, food production, religious practices) } \\
\text { B: Antibacterial compound activity } \\
\text { C: surfactants, nutrients, fertilizers, pesticides }\end{array}$ & \\
\hline $6.67 \%$ & $\begin{array}{l}\text { Pathogens in water } \\
\text { A: Human-bacteria interface } \\
\text { B: Importance of water in life } \\
\text { C: Hydrophilicity/phobicity, adsorption in the body }\end{array}$ & $\begin{array}{l}\text { Introduction to neglected tropical } \\
\text { diseases }\end{array}$ \\
\hline $6.67 \%$ & $\begin{array}{l}\text { Historical context of epidemics } \\
\text { Epidemiology and the spread of diseases } \\
\text { A: Cultural/historical factors impacting } \\
\quad \text { development/spread of epidemics } \\
\text { B: Spread of disease in populations } \\
\text { C: kinetics of transport in the body (bacteria and } \\
\quad \text { drug) }\end{array}$ & $\begin{array}{l}\text { Multidisciplinary approaches to } \\
\text { addressing water-borne diseases }\end{array}$ \\
\hline $6.67 \%$ & $\begin{array}{l}\text { Bacterial ecosystems } \\
\text { A: Human interaction with bacterial ecosystem } \\
\text { B: Bacterial survival in water } \\
\text { C: water systems (fresh, sea, brackish) }\end{array}$ & Intervention case study analysis \\
\hline $6.67 \%$ & $\begin{array}{l}\text { Biochemistry of cholera } \\
\text { Treatment of cholera } \\
\text { A: Human activities that impact contraction/spread } \\
\quad \text { of cholera } \\
\text { B: Cholera life cycle, toxin action } \\
\text { C: Ion exchange in the body }\end{array}$ & Intervention case study analysis \\
\hline $6.67 \%$ & $\begin{array}{l}\text { Cholera outbreaks in the U.S., India, Haiti } \\
\text { Water treatment as prevention of cholera } \\
\text { A: Indigenous approaches to disease prevention and } \\
\quad \text { treatment } \\
\text { B: Susceptibility of cholera to antibacterials } \\
\text { C: Solutions, impurities, water transport }\end{array}$ & Intervention case study analysis \\
\hline $6.67 \%$ & $\begin{array}{l}\text { Municipal water treatment in a global context } \\
\text { A: Cultural factors affecting development of water } \\
\quad \text { treatment } \\
\text { B: Action of bacteria and toxins } \\
\text { C: Overview: filtration, sedimentation, biological } \\
\quad \text { purification, toxins (e.g. Arsenic) }\end{array}$ & $\begin{array}{l}\text { Resolutions to solving existing problems } \\
\text { in water treatment }\end{array}$ \\
\hline $6.67 \%$ & $\begin{array}{l}\text { Physical water treatment methods } \\
\text { A: Impact of physical water treatment methods on } \\
\text { local/regional populations } \\
\text { B: Prokaryotic cell structure } \\
\text { C: Filtration, flocculation, ion exchange, } \\
\text { membranes, sterilization }\end{array}$ & Water conservation \\
\hline $6.67 \%$ & $\begin{array}{l}\text { Biological water treatment methods } \\
\text { A: Impact of biological water treatment methods on } \\
\quad \text { local/regional populations } \\
\text { B: Susceptibility of bacteria to biological water } \\
\text { treatment } \\
\text { C: anaerobic, aerobic, use of sludge, nutrient cycles, } \\
\text { toxins }\end{array}$ & Poster and podium presentation basics \\
\hline $6.67 \%$ & $\begin{array}{l}\text { Structural inequalities to water treatment and health } \\
\text { A: Political, social, economic power structures and } \\
\text { clean water access } \\
\text { B: Inequalities in water supplies and contaminants } \\
\text { C: drinking water and wastewater systems in US } \\
\text { and Haiti }\end{array}$ & Group work day \\
\hline $6.67 \%$ & $\begin{array}{l}\text { Human right to fresh water (United Nations) } \\
\text { Potential legal consequences to unequal access to } \\
\quad \text { clean water } \\
\text { A: Political, social, economic power structures and }\end{array}$ & SRCEE presentation week \\
\hline
\end{tabular}

Journal of the Scholarship of Teaching and Learning, Vol. 14, No. 2, May 2014. 
Mueller, A., Juris, S. J., Willermet, C., Drake, E., Upadhaya, S., \& Chhetri, P.

\begin{tabular}{|l|l|l|}
\hline & \multicolumn{1}{|c|}{ clean water access } \\
& $\begin{array}{l}\text { B: Examples of contaminants in water systems } \\
\text { C: e.g. water in Arizona (arsenic) }\end{array}$ & \\
\hline $6.67 \%$ & $\begin{array}{l}\text { New water treatment solutions } \\
\text { A: Cultural factors affecting adoption of new } \\
\text { technologies } \\
\text { B: Susceptibility of pathogens to new treatment } \\
\text { examples } \\
\text { C: simple filtration and sterilization methods }\end{array}$ & Discussion and next steps \\
\hline Finals week & Examination & Final presentations due \\
\hline
\end{tabular}

\section{Suggested Course Evaluation}

$20 \% \quad$ Journal entries on seminar readings (e.g., ten 1-page journal entries)

$20 \%$ In-class participation/group discussion (e.g., free writes, clicker activities)

$20 \%$ Written assignments (e.g., three 3-4 page essays) highlighting interdisciplinary content analysis

$20 \% \quad$ Pre/post examinations, with multiple choice/short answer questions

$20 \%$ Presentation in seminar on grassroots campaign for water issues

\section{Bibliography}

Alley KD. 2002. On the Banks of the Ganga: When Wastewater Meets a Sacred River. Ann Arbor: University of Michigan Press.

Alley KD. 1994. Ganga and Gandagi: interpretations of pollution and waste in Benaras. Ethnology 33(2): 127-145.

Baer H, Singer M, Susser I. 2003. Medical Anthropology and the World System. $2^{\text {nd }}$ edition. Westport, CT: Bergin and Garvey.

Bakker K. 2010. Privatizing Water: Governance Failure and the World's Urban Water Crisis. Ithaca: Cornell University Press.

Barlow M, Clark T. 2002. Blue Gold: The Fight to Stop the Corporate Theft of the World's Water. New York: The New York Press.

Barzilay EJ, Aghoghovbia TS, Blanton EM, Akinpelumi AA, Coldiron ME, Akinfolayan O, Adeleye OA, LaTrielle A, Hoekstra RM, Gilpin U, Quick R. 2011. Diarrhea prevention in people living with HIV: an evaluation of a point-of-use water quality intervention in Lagos, Nigeria. AIDS Care 23(3): 330-339.

Bennett V. 1995. The Politics of Water: Urban Protest, Gender, and Power in Monterrey, Mexico. Pittsburgh: University of Pittsburgh Press.

Berrittella M, Hoekstra AY, Rehdanz K, Roson R, Tol RS. 2007. The economic impact of restricted water supply: a computable general equilibrium analysis. Water Research 41(8) 1799-1813.

Binnie C, Kimber M, Smethhurst G. 2002. Basic Water Treatment. $3^{\text {rd }}$ edition. London: Royal Society of Chemistry.

Black M, King J. 2009. The Atlas of Water. $2^{\text {nd }}$ edition. Berkeley: University of California Press.

Journal of the Scholarship of Teaching and Learning, Vol. 14, No. 2, May 2014. 
Mueller, A., Juris, S. J., Willermet, C., Drake, E., Upadhaya, S., \& Chhetri, P.

Bodley JH. 1996. Anthropology and Contemporary Human Problems. Mountain View, CA: Mayfield Publishing Company.

Charles RC, Ryan ET. 2011. Cholera in the $21^{\text {st }}$ century. Current Opinion in Infectious Disease 24:472477.

Cifuentes E, Blumenthal U, Ruiz-Palacios G. 1995. Riego agrícola con aguas residuales y sus efectos sobre la salud en México. In: Restrepo I (editor), Agua, Salud, y Derechos Humanos. México, DF: Comisión Nacional de Derechos Humanos. pp. 189-201.

Cox S, Annis S. 1988. Community participation in rural water supply. In: Annis S, Hakim P (editors), Direct to the Poor: Grassroots Development in Latin America. Boulder, CO: Lynne Rienner Publishers. pp. 65-72.

DeVilliers M. 2001. Water: the Fate of Our Most Precious Resource. Boston: Houghton Mifflin.

Doolittle WE. 1990. Canal Irrigation in Prehistoric Mexico: The Sequence of Technological Change. Austin: University of Texas Press.

Ennis-McMillan MC. 2006. A Precious Liquid: Drinking Water and Culture in the Valley of Mexico. Belmont, CA: Thomson Wadsworth.

Fagan B. 2011. Elixir: A History of Water and Humankind. London: Bloomsbury Press.

Farmer P. 2003. Pathologies of Power: Health, Human Rights, and the New War on the Poor. Berkeley: University of California Press.

Gerbens-Leens W, Hoekstra AY. 2012. The water footprint of sweeteners and bio-ethanol. Environment International 40: 202-211.

Gelles PH. 2000. Water and Power in Highland Peru: The Cultural Politics of Irrigation and Development. New Brunswick, NJ: Rutgers Uiversity Press.

Gleick PH. 1996. Basic water requirements for human activities: meeting basic needs. Water International 21: 83-92.

Gleick PH. 1999. The human right to water. Water Policy 1(5): 487-503.

Gleick PH, editor. 1993. Water in Crisis: A Guide to the World's Fresh Water Resources. Oxford: Oxford University Press.

Greene SK, Daly ER, Talbot EA, Demma LJ, Holzbauer S, Patel NJ, Hill TA, Walderhaug MO, Hoekstra RM, Lynch MF, Painter JA. 2008. Recurrent multistate outbreak of Salmonella newport associated with tomatoes from contaminated fields, 2005. Epidemiology and Infection 136(2): 157-165.

Gupta SK, Sheikh MA, Islam MS, Rahman KS, Jahan N, Rahman MM, Hoekstra RM, Johnston R, Ram PK, Luby S. 2008. Journal of Applied Microbiology 104(2): 388-395.

Journal of the Scholarship of Teaching and Learning, Vol. 14, No. 2, May 2014. 
Mueller, A., Juris, S. J., Willermet, C., Drake, E., Upadhaya, S., \& Chhetri, P.

Gupta SK, Suantio A, Gray A, Widyastuti E, Jain N, Rolos R, Hoekstra RM, Quick R. 2007. Factors associated with $E$. coli contamination of household drinking water among tsunami and earthquake survivors, Indonesia. American Journal of Tropical Medicine and Hygiene 76(6): 1158-1162.

Hoekstra AY, Mekonnen MM. 2012. The water footprint of humanity. Proceedings of the National Academy of Sciences, Early Edition, published ahead of print February 13, 2012.

Hoff H. 2009. Global water resources and their management. Current Opinions in Environmental Sustainability 1: 141-147.

Jain S, Sahanoon OK, Blanton E, Schmitz A, Wannemuehler KA, Hoekstra RM, Quick RE. 2010. Sodium dichloroisocyanurate tablets for routine treatment of household drinking water in periurban Ghana: a randomized controlled trial. American Journal of Tropical Medicine and Hygiene 82(1): 16-22.

Luby SP, Agboatwalla M, Painter J, Altaf A, Billhimer W, Keswick B, Hoekstra RM. 2006. Combining drinking water treatment and hand washing for diarrhoea prevention, a cluster randomised controlled trial. 2006. Tropical Medicine and International Health 11(4): 479-489.

Metcalf E. 2005. Wastewater Engineering, Treatment, and Reuse. $4^{\text {th }}$ edition. New Delhi: Tata McGraw Hill.

Morris RD. 2007. The Blue Death: Disease, Disaster, and the Water We Drink. New York: HarperCollins Press.

Nelson EJ, Harris JB, Morris JG Jr, Calderwood SB, Camilli A. 2009. Cholera transmission: the host, pathogen, and bacteriophage dynamic. Nature Reviews Microbiology 7:693-702.

Nichter M. 1985. Drink boiled water: a cultural analysis of a health education message. Social Science and Medicine 21(6): 667-669.

O’Reilly CE, Bowen AB, Perez NE, Sarisky JP, Shepherd CA, Miller MD, Hubbard BC, Herring M, Buchanan SD, Fitzgerald CC, Hill V, Arrowood MJ, Xiao LX, Hoekstra RM, Mintz ED, Lynch MF. 2007. A waterborne outbreak of gastroenteritis with multiple etiologies among resort island visitors and residents: Ohio, 2004. Clinical Infectious Diseases 44(4): 506-512.

O’Reilly CE, Freeman MC, Ravani M, Migele J, Mwaki A, Ayalo M, Ombeki S, Hoekstra RM, Quick R. 2008. The impact of a school-based safe water and hygiene programme on knowledge and practices of students and their parents: Nyanza Province, western Kenya, 2006. Epidemiology and Infection 136(1): 80-91.

Paul BD. 1977. The role of beliefs and customs in sanitation programs. In: Landy D (editor), Culture, Disease, and Healing. New York: Macmillan Press. pp. 233-236.

Reisner M. 1986. Cadillac Desert: The American West and its Disappearing Water. New York: Viking Press.

Restrepo I (Editor). 1995. Agua, Salud, y Derechos Humanos. México, DF: Comisión Nacional de Derechos Humanos.

Journal of the Scholarship of Teaching and Learning, Vol. 14, No. 2, May 2014. 
Mueller, A., Juris, S. J., Willermet, C., Drake, E., Upadhaya, S., \& Chhetri, P.

Ritchie JM, Waldor MK. 2009. Vibrio cholerae interactions with the gastrointestinal tract: lessons from animal studies. Current Topics in Microbiology and Immunology 337:37-59.

Solomon S. 2010. Water, the Epic Struggle for Wealth, Power, and Civilization. New York: Harper Perennial.

Van der Leeden F, Troise FL, Todd DK. The Water Encyclopedia. $2^{\text {nd }}$ edition. Boca Raton, FL: CRC Press.

Well AA, Ivers LC, Harris JB. 2012. Cholera: lessons from Haiti and beyond. Current Infectious Disease Reports 14: 1-8.

Whiteford LM. 1997. The ethnoecology of dengue fever. Medical Anthropology Quarterly 11(2): 202223. 


\section{Appendix 2: Interdisciplinary assessment rubric.}

\section{Interdisciplinary Project Rubric}

\begin{tabular}{|c|c|c|c|c|}
\hline & Proficient (4) & Acceptable (3) & Developing (2) & Deficient (1) \\
\hline \multicolumn{5}{|l|}{ Disciplinary Grounding } \\
\hline $\begin{array}{l}\text { Clarity: Explanation } \\
\text { of disciplinary insights, } \\
\text { methods, findings, } \\
\text { mode of thinking is free } \\
\text { from confusion and } \\
\text { ambiguity. }\end{array}$ & $\begin{array}{l}\text { All disciplinary } \\
\text { explanations are clear } \\
\text { in purpose and } \\
\text { organization. }\end{array}$ & $\begin{array}{l}\text { All but one } \\
\text { disciplinary } \\
\text { explanations are clear } \\
\text { in purpose and } \\
\text { organization; or } \\
\text { several miss either } \\
\text { purpose or } \\
\text { organization }\end{array}$ & $\begin{array}{l}\text { Only one } \\
\text { disciplinary } \\
\text { explanation is clear } \\
\text { in purpose and } \\
\text { organization; or all } \\
\text { miss either purpose } \\
\text { or organization }\end{array}$ & $\begin{array}{l}\text { None of the disciplinary } \\
\text { arguments are clear }\end{array}$ \\
\hline $\begin{array}{l}\text { Logical: Each } \\
\text { disciplinary argument } \\
\text { fits together well, } \\
\text { conclusions follow } \\
\text { from reasoning and } \\
\text { evidence; well- } \\
\text { reasoned; plausible, } \\
\text { consistent, coherent. }\end{array}$ & $\begin{array}{l}\text { All disciplinary } \\
\text { arguments are } \\
\text { logical, coherent, and } \\
\text { based on evidence }\end{array}$ & $\begin{array}{l}\text { All but one } \\
\text { disciplinary } \\
\text { arguments are } \\
\text { logical, coherent, and } \\
\text { based on evidence }\end{array}$ & $\begin{array}{l}\text { Only one } \\
\text { disciplinary } \\
\text { argument is logical, } \\
\text { coherent, and based } \\
\text { on evidence }\end{array}$ & $\begin{array}{l}\text { None of the disciplinary } \\
\text { arguments are logical, } \\
\text { coherent, and based on } \\
\text { evidence }\end{array}$ \\
\hline $\begin{array}{l}\text { Complete: Includes all } \\
\text { disciplinary information } \\
\text { needed; lacking none of } \\
\text { its parts or aspects } \\
\text { thorough, whole. }\end{array}$ & $\begin{array}{l}\text { All disciplinary } \\
\text { information needed is } \\
\text { presented. }\end{array}$ & $\begin{array}{l}\text { Most of the } \\
\text { disciplinary } \\
\text { information needed is } \\
\text { presented. }\end{array}$ & $\begin{array}{l}\text { Only some of the } \\
\text { disciplinary } \\
\text { information needed } \\
\text { is presented. }\end{array}$ & $\begin{array}{l}\text { None of the disciplinary } \\
\text { information needed is } \\
\text { presented. }\end{array}$ \\
\hline \multicolumn{5}{|c|}{ Interdisciplinary Reasoning } \\
\hline $\begin{array}{l}\text { Integrative Summary: } \\
\text { All disciplinary } \\
\text { arguments are distilled } \\
\text { into a coherent } \\
\text { summary with an } \\
\text { overall meaning or } \\
\text { result. }\end{array}$ & $\begin{array}{l}\text { All disciplinary } \\
\text { information has been } \\
\text { included in the } \\
\text { summary in a logical } \\
\text { manner. }\end{array}$ & $\begin{array}{l}2 \text { disciplines are } \\
\text { favored over the } 3^{\text {rd }} \text {. }\end{array}$ & $\begin{array}{l}1 \text { discipline is } \\
\text { favored over all } \\
\text { other disciplines. }\end{array}$ & $\begin{array}{l}\text { No integrative summary } \\
\text { is attempted. }\end{array}$ \\
\hline $\begin{array}{l}\text { Conceptual Bridging: } \\
\text { A particular concept, } \\
\text { instrument, skill is used } \\
\text { in a variety of concepts } \\
\text { resulting in a deeper } \\
\text { understanding of the } \\
\text { tool itself. }\end{array}$ & $\begin{array}{l}\text { The topic is } \\
\text { investigated from the } \\
\text { viewpoint of all } \\
\text { disciplines, leading to } \\
\text { deeper understanding } \\
\text { of the topic. }\end{array}$ & $\begin{array}{l}2 \text { disciplines are } \\
\text { favored over the } 3^{\text {rd }} \text {. }\end{array}$ & $\begin{array}{l}1 \text { discipline is } \\
\text { favored over all } \\
\text { other disciplines. }\end{array}$ & $\begin{array}{l}\text { No deeper } \\
\text { understanding has been } \\
\text { achieved. }\end{array}$ \\
\hline $\begin{array}{l}\text { Complex Explanation: } \\
\text { The interdisciplinary } \\
\text { argument is developed } \\
\text { to a higher level of } \\
\text { abstraction }\end{array}$ & $\begin{array}{l}\text { Coherent whole is } \\
\text { synthesized to a } \\
\text { higher level of } \\
\text { abstraction }\end{array}$ & $\begin{array}{l}\text { Several parts of the } \\
\text { bridged concepts are } \\
\text { developed to a higher } \\
\text { level of abstraction }\end{array}$ & $\begin{array}{l}\text { A few parts of the } \\
\text { bridged concepts are } \\
\text { developed to a } \\
\text { higher level of } \\
\text { abstraction }\end{array}$ & $\begin{array}{l}\text { Abstraction has not } \\
\text { been attempted }\end{array}$ \\
\hline \multicolumn{5}{|c|}{ For final seminar project only: Pragmatic solution } \\
\hline $\begin{array}{l}\text { Pragmatic Solution: } \\
\text { A practical problem is } \\
\text { solved by the inclusion } \\
\text { of all disciplinary } \\
\text { perspectives }\end{array}$ & $\begin{array}{l}\text { The pragmatic } \\
\text { solution plan is } \\
\text { interdisciplinary and } \\
\text { includes all processes } \\
\text { of } 6 \sigma: \text { define, } \\
\text { measure, analyze, } \\
\text { improve, and control }\end{array}$ & $\begin{array}{l}\text { The pragmatic } \\
\text { solution plan is } \\
\text { interdisciplinary } \\
\text { includes at least } 4 \text { of } \\
\text { the processes of } 6 \sigma \text { : } \\
\text { define, measure, } \\
\text { analyze, improve, } \\
\text { and control }\end{array}$ & $\begin{array}{l}\text { The pragmatic } \\
\text { solution plan only } \\
\text { includes only } 2 \text { out } \\
\text { or fields or only } 3 \text { of } \\
\text { the processes of } 6 \sigma \text { : } \\
\text { define, measure, } \\
\text { analyze, improve, } \\
\text { and control }\end{array}$ & $\begin{array}{l}\text { The problem was not } \\
\text { solved in an } \\
\text { interdisciplinary } \\
\text { manner or did not } \\
\text { include } 6 \sigma \text { processes. }\end{array}$ \\
\hline
\end{tabular}


Mueller, A., Juris, S. J., Willermet, C., Drake, E., Upadhaya, S., \& Chhetri, P.

\section{References}

Barisonzi, J., \& Thorn, M. (2003). Teaching Revolution: Issues in Interdisciplinary Education. College Teaching, 51(1), 5-8. doi: 10.1080/87567550309596402

Barkley, E. F., Cross, K. P., \& Major, C. H. (2005). Collaborative Learning Techniques: A Handbook For College Faculty. San Francisco, CA: Jossey-Bass.

Begg, M. D., \& Vaughan, R. D. (2011). Are Biostatistics Students Prepared to Succeed in the Era of Interdisciplary Science? (And How Will We Know?) The American Statistician, 65(2), 71-79. doi: 10.1198/tast.2011.10222

DeZure, D. (2010). Interdisciplinary Pedagogies in Higher Education. In R. Frodeman, J. Thompson Klein, \& C. Mitcham (Eds.), The Oxford Handbook of Interdisciplinarity (372-386). Oxford, England: Oxford University Press. doi: 10.3200/CTCH.57.2.99-104

Eisen, A., Hall, A., Lee, T. S., \& Zupko, J. (2009). Teaching Water: Connecting Across Disciplines and into Daily Life to Address Complex Societal Issues. College Teaching, 57(2), 99-104.

Elder L., Paul R. (2013). The National Council for Excellence in Critical Thinking. Retrieved from http://www.criticalthinking.org/pages/the-national-council-for-excellence-incritical-thinking/406.

Haynes, C. (n.d.). Designing and Teaching an Interdisciplinary Course: Paper presented at Teaching Outside the Lines workshop, John Hope Franklin Humanities Institute, Durham, NC.

Kuh, G.D. (2008). High-Impact Educational Practices: What They Are, Who Has Access to Them, and Why They Matter. AAC\&U.

Mansilla, V.B., \& Duraisingh, E.D. (2007). Targeted Assessment of Students' Interdisciplinary Work: An Empirically Grounded Framework Proposed. The Journal of Higher Education, 7 (2), 215-237. doi: 10.1353/jhe.2007.0008

Motorola University (1994). The Inventors of Six Sigma. http://web.archive.org/web/20051106025733/http://www.motorola.com/content/0,3079,00.html. Archived from the original on November 6, 2005. Retrieved June 7, 2013.

Nilson, L. B., (2010). Teaching at its Best. (3rd Ed.). San Francisco, CA: Jossey-Bass.

Nissani, M. (1997). Ten Cheers for Interdisciplinarity: The Case for Interdisciplinary Knowledge and Research. The Social Science Journal, 34(2), 201-216. doi: 10.1016/S03623319(97)90051-3

Prince, M. (2004), Does Active Learning Work? A Review of the Research. Journal of Engineering Education, 93, 223-231. doi: 10.1002/j.2168-9830.2004.tb00809.x 
Mueller, A., Juris, S. J., Willermet, C., Drake, E., Upadhaya, S., \& Chhetri, P.

R (2013) R for Mac OS X, http://cran.r-project.org/bin/macosx/

Real Statistics (2013) Real Statistics Resource Pack, downloaded Sept. 24, 2013)

http://www.real-statistics.com/free-download/real-statistics-resource-pack/.

Sternberg, R.J. (2008). Interdisciplinary Problem-Based Learning: An Alternative to Traditional Majors and Minors. Liberal Education, 94(1), 12-17.

Willermet, C., Mueller, A., Juris, S.J., Drake, E., Upadhaya, S., \& Chhetri, P. (2013) Water as Life, Death, and Power: Building an Integrated Interdisciplinary Course Combining Perspectives From Anthropology, Biology, and Chemistry. Journal of the Scholarship of Teaching and Learning, 13(5), 105-123. 